\title{
Determinants of the Intention to Buy Clothes in the Online Stores of the MiPyMe of Perú, Colombia and México
}

\author{
Elizabeth Emperatriz García-Salirrosas 1, *, Paula Andrea Mejía Henao 2, Reyna Esperanza Zea Gordillo³, Juan Car- \\ los Olaya Molano², James Aristides Pajuelo Rodriguez ${ }^{4}$
}

1 Department of Humanities, Faculty of Business Studies, Universidad Privada del Norte, Lima 15314, Perú; elizabeth.garcial@upn.edu.pe

2 Faculty of Economic and Administrative Sciences, Universidad San Buenaventura, Bogotá, Colombia; pamejia@usbbog.edu.co and jolaya@usbbog.edu.co

3 Faculty of Administrative Sciences and Digital Technology, Universidad de Ciencias y Artes de Chiapas con sede Villa Corzo, México; reyna.zea@unicach.mx

4 Faculty of Truth Management Sciences, Universidad Autónoma del Perú, Perú; apajuelor@autonoma.edu.pe

* Correspondence: elizabeth.garcial@upn.edu.pe

\begin{abstract}
With the recent coronavirus pandemic (Covid-19) online sales of clothing retail have become a necessity to survive in the market. It is for this reason that the objective of the research was to know the purchase intention of clothing by young consumers through the online channel of small and micro companies (MiPyMe) located in the countries of Mexico, Colombia and Peru. To do this, using a structural equations model, it was intended to analyze the relationships between the variables trust, satisfaction, perceived value, quality of interaction and image in the electronic context as antecedent variables of online purchase intention, in accordance with the theoretical framework. 638 surveys were applied to young consumers in Mexico, Colombia and Peru. Sociodemographic characteristics included gender, age, country, and knowledge of a MiPyMe online clothing store. The results reveal that, of the total of young people surveyed, $62.7 \%$ stated that they did not know of any online clothing store of a MiPyMe. The contrasting of the hypotheses indicates that the quality of interaction directly and positively influences perceived value, that the image directly and positively influences the satisfaction and purchase intention of the consumer of the MiPyMe of Colombia, Mexico and Peru. These results may be useful for entrepreneurs in this business sector to rethink their online business strategies, as well as for the governments of these nations to promote this sector with training and specialized technical assistance.
\end{abstract}

Keywords: Perceived value, quality of interaction, image, trust and satisfaction.

\section{Introduction}

We are currently living immersed in a new digital era in which every company or organization needs to digitize its processes, businesses need new forms of commercialization and marketing strategies that allow them to position their products and services offered. With the recent coronavirus pandemic (Covid-19), online retail textile sales have become a necessity (1).

Electronic commerce (e-commerce) is today a competitive strategy, and a tool to remain competitive (2). Thanks to the rise of e-commerce, online shopping is the main way people buy clothes. In China's online shopping, clothing consumption accounts for more than $60 \%$ of e-commerce, yet it still faces many problems (3); Furthermore, in Latin American countries such as Mexico, where retail industries were forced during the pandemic to migrate to digital channels, sell online, manage businesses remotely, reinvent themselves and innovate to survive and meet customer expectations. turned into a titanic challenge (4). 
Before the pandemic, $76 \%$ of Latin American Internet users had accessed online stores (Alderete, 2019), and after the pandemic these figures increased enormously. In Mexico, according to estimates by the AMVO (Mexican Association of Online Sales), electronic commerce grew by at least $80 \%$ last year (5); Colombia registered a $44.3 \%$ increase in online sales compared to the first quarter of 2020 (6); and in Peru after COVID-19, online purchases have come to lead the market, with a growth of $51.77 \%$ (7).

The Internet has drastically changed consumer behavior and purchasing habits and has shaken the retail landscape, becoming an important channel for the sale of clothing products (8)(9); In this way, electronic commerce and the omnichannel model have guided the transformation of the business models of clothing brands in the world (10). A new model, which pushes companies to develop the capacity to supply their consumers and generate good experiences in them (7); in addition to benefiting manufacturers and small and micro companies (MiPyMe) of online clothing retailing, reducing their returns and increasing their sales and profitability (1).

Online shopping is almost a pure visual experience, where consumers visit virtual stores, search for the items they want, compare features and prices, choose the perfect item and place their order through Internet services (11) (12). When shopping online, consumers need a long time to search for all compatible products, and they often shop at more than one of the retail brands; Therefore, brand advertising greatly influences the purchase decision in any of the virtual stores visited by customers (13) (14).

Ultimately, retailers play an important role in managing the fashion supply chain, with fashion and apparel being one of the fastest growing categories online. That is why the digital age presents opportunities for retailers to bring higher levels of operational efficiency and customer focus to their business models (15). In addition, predicting the trend of the retail apparel industry in the post-epidemic era, will help optimize the apparel industry chain, improve efficiency, and help the retail apparel industry meet the trend of the times (16).

In this context, the present research work aims to identify and relate the variables that are involved in the purchase intention of young consumers in the online clothing stores of the MiPyMe of Colombia, Mexico and Peru, under this new scheme post-pandemic. The results will serve to diagnose this sector in terms of the adoption of new digital technology on the internet to enhance marketing through this channel and electronic commerce and thus serve as a reference to promote public policies and strategic actions to promote the development of this business sector.

This motivation will be outlined through the consumer's purchase intention in the online distribution channel. The determinants for said intention in this work, according to the evidence found in the literature, will be the quality of the interaction, trust, image, satisfaction and perceived value.

\section{Reality of the MyPyMe of Colombia, Mexico and Peru}

The MiPyMe in Colombia support the country's economy, representing 99\% of the total number of existing companies (17). Various problems are handled around the MiPyMe in Colombia such as: a) expensive and limited financing (only half of these can access credit), b) informality (due to business and labor costs associated with formalization), c) high costs of registering, producing and marketing their products, d) little investment in innovation, research and development, technology and processes (19), e) low levels of liquidity and f) low productivity (20); COVID-19 further accentuated these problems, added to the drop in sales that this crisis represented (21).

According to the Superintendency of Companies of Colombia, the production, sales, exports and imports of the textile and clothing sector has presented a moderate fluctuation between 2016 and 2017, while 2018 presents somewhat encouraging figures, however, the balance of exports vs. imports is negative for these 3 years (22). During the COVID-19 pandemic, the National Government of Colombia, through the National Guarantee Fund 
(FNG), implemented a package of measures for the MiPyMe, which sought to facilitate access to credits for the payment of payroll and working capital (23).

In Mexico, in 2019 there were 4.9 million MiPyMe, of which as a result of the pandemic, they were reduced to 3.9 million (79.19\%), just over a million (20.81\%) of establishments that closed their doors permanently. However, 619 thousand 443 establishments were born, representing $12.75 \%$ of the country's business population (25). The main problems faced by the establishments in the face of the health contingency due to COVID-19 were closures and variations in personnel. Therefore, the financial support received by the MiPyMe during the COVID-19 contingency was used for debt payments to suppliers, acquisition of supplies, rent payments, etc. (26).

On the other hand, in Metropolitan Lima-Peru, the companies that remained operational during the pandemic had to adopt various sales methods: face-to-face and delivery $25.8 \%$, online $25.3 \%$, face-to-face $24.5 \%$, delivery $14,4 \%$, other modality $10 \%$ (mixed modality: delivery - online, face-to-face - online, among others). The companies had to face problems of decreased demand, high health security costs, delay in the collection of invoices, production stoppage, loss of working capital, shortage of raw materials and supplies, illness of workers due to Covid-19, difficulty in exporting their products, etc. (27) (27). The companies had to access a program implemented by the government to be able to address various financial problems such as: Difficulties in charging customers, lack of liquidity to buy materials and pay suppliers, limitations to access financing sources, lack of liquidity to paying salaries, difficulty in paying loans, difficulty in accessing supplier credit, among others (27).

\section{Theoretical Framework}

\section{Purchase intent}

Purchasing intention refers to the subjective willingness of consumers to purchase ecommerce clothing (28). The purchase intention is a plan to acquire a certain product or service; a purchase can be completely planned or impulsive, this will depend on factors such as culture, social class and the situation of the people who want to make the purchase. Likewise, the resources, attitudes and lifestyle of the consumer are also considered influencing factors (12)

According to economic theory, consumers choose an item to buy rationally and based on their limited resources (29). While, from the psychological perspective, Ajzen (1996) considers the purchase intention as the will that the consumer manifests in terms of effort and action to carry out a certain behavior, which according to Zeithaml (1988), is associated with a set of variables such as previous experience, preferences and external environment to collect information, evaluate alternatives and finally make a purchase decision (31).

In the clothing buying process, visual attention is a key element that influences the consumer's purchase decision; Visual factors of clothing such as shape, color, and pattern are more important than comfort, warmth, and ventilation. The emotional experience of clothing objects is gradually formed and ultimately a purchasing decision is made (11).

In the electronic context, the purchasing intentions of consumers are affected by several factors related to the information system such as the quality of the website, the design of web pages and the display of product details. Therefore, online stores need to differentiate themselves to attract customers with their unique features and capture their best first impressions (32).

Electronic purchase intent reflects the desire of customers to purchase over the Internet. It is believed that a buyer is more likely to buy from virtual stores when e-commerce sites provide satisfactory tools, including product or service catalogs, search functions, price comparison sheets, shopping carts, online payment systems and description devices (33) (34). From the point of view of personality, the intention to buy online can be seen as a lasting disposition of the consumer to show certain buying behavior in a certain context mediated by an electronic device (35). 


\section{Interaction quality}

The quality of the interaction is a different construct from the quality of the product or service (36). The quality of interaction in online shopping enriches the retail offer of additional content, both functional and social, amplifying its commercial and emotional appeal through the new dimensions of continuity interaction intentions capable of creating a virtuous circle (37).

Digital technologies provide opportunities for retailers to acquire new customers, better interact with existing customers, reduce costs, and improve employee motivation (15). In this sense, interaction on social networks has allowed consumers to bond with each other by exchanging information, recommendations and opinions about products and services (38).

In online shopping platforms, virtual assistants have become an essential element for communication between consumers and merchants, helping consumers to make complex purchase decisions and provide a smart and satisfying interactive experience to users through the quality of interaction with consumers (39). In addition, the quality of service implies a comparison between what the client expects to receive as expectations before the service and what they have actually received as performance of the service result (40).

High levels of satisfaction and loyalty arise from the experiential values accumulated by customers in contact with retailers (37). The quality of interaction in electronic commerce is influenced by the quality of the information perceived, which plays an important role in customer satisfaction, attitudes and loyalty towards electronic commerce (38).

The quality of the interaction is then an intangible value implicit in the sale by electronic commerce, including the value of the brand and the service (28). New digital technologies have allowed consumers to evaluate fashion online, creating an interactive and exciting shopping experience. Fashion brands also face changing customer expectations such as higher quality individualized products, fast delivery and comprehensive services before and after purchase, free shipping and regular updates (15). Achieving continuous interactions requires strategies such as creating brand or company pages on microblogging platforms so that companies connect with their consumers and bring them closer to each other (37).

Informational social influence theory predicts how individuals can be socially influenced, when an individual's actions or thoughts are affected by the actions, opinions, and words of others; on the other hand, the heuristic-systematic model of information processing explains how people receive and process persuasive messages. In systematic processing people examine the message in an analytical and exhaustive way and form their attitudes based on the visual content, and in heuristic processing people make less cognitive effort to process the information and tend to form their attitudes based on heuristic clues. (38).

Interactivity in an online shopping context (e-interaction) refers to the degree of communication between consumers and electronic retailers, anytime, anywhere (41). The customer-supplier interaction is made easier and easier thanks to virtual servers, these agents can be an online extension of the marketing and sales function to guide customers in their virtual purchasing process (42). According to (43), the customer's human-computer interaction plays an important role in the perceived value of the electronic service (e-service).

H1. The quality of the interaction directly and positively influences the perceived value of the consumer of the MiPyMe online clothing store.

\section{Image}

For Dobni and Zinkhan (1990) cited by (44), the brand image is built from the total perceptions of consumers, whether rational or emotional (pp. 48, 49), whose associations they are structured in their minds. Susanto \& Wijanarko, (2014) cited by (46) point out that the brand image serves to differentiate a brand or product from its competitor. A strong 
and positive brand image means that: a) a company succeeds in acquiring new customers and retaining old ones, $b$ ) customers are willing to pay a higher price.

The image concept can be applied to different targets, such as products, individual and corporate brands, geographical areas, events and even specific people (48. The brand image can be defined as the perception that arises in the minds of consumers when considering the brand of a certain product, differentiating it from competitors. In the corporate image, on the other hand, consumers compare various attributes that the company possesses: the product, the price, the quality of the product and the quality of the service (12).

The corporate image is a projection of the internal image of the company to the public, that is, the company treats its image from within, which will prevent a certain audience from having such a real perception of the company's image (49). The image influences consumer behavior (36), as a consequence of the reputation of the company that can generate credibility or mistrust among the community (50).

Every company tries to show the superiority of its product compared to other products. However, the well-formed brand image does not change in the short term because they are formed through a long process over a long period of time. Therefore, there is a direct and positive effect of the brand image on the purchase decision (51).

Empirical studies have confirmed that the perceived value of the online store image in an online shopping environment can lead to intentional and impulsive buying behavior. The perceived value of the purchase intention is based on the symbolic and functional attributes of the product, while the utilitarian value is reflected in the practicality, comfort and cost savings experienced by consumers in the purchase process (52).

Digitization is helping to optimize supply chains and operations, process information and knowledge faster, optimize the use of raw materials and reduce energy consumption to maintain the sustainability of a business. In addition, consumers are willing to pay more for ethical products, generating for retailers who adopt business practices of sustainability, savings, attracting new customer segments, improving reputation and greater employee engagement (15).

The e-image includes the reputation, quality of the information on the web, the performance of the quality of the service and any other factor that represents the image of the company. The e-image or online image, allows the sustainability of a business by generating reliability, credibility and integrity on the part of the company and individuals in an online environment; therefore, a positive e-image favors the decision to purchase a product that may have a higher price than the competition (53). Consequently, the image of an online retail store or the e-tailer image, allows positive associations with the brand, word of mouth marketing and perception of customer value (54), showing that the more positive the image, more notable is the degree of customer satisfaction (55).

H2. The image of the online store positively influences the perceived value of the consumer of the MiPyMe online clothing store.

H3. The image of the online store positively influences consumer satisfaction of the MiPyMe online clothing store.

H4. The image of the online store positively influences the online purchase intention of the consumer of the MiPyMe online clothing store.

\section{Confidence}

Trust occurs when a consumer buys a product based on clear expectations. Because consumers are exposed to uncertainty and risk, trust is the foundation of any business; Generating trust in long-term relationships with clients is an important factor to retain them (39) (12). (56) define trust as the perception that a party has towards its partner in terms of reliability and integrity (31).

Brand trust is one of the most important factors that directly influences brand loyalty. It consists of the belief that consumers take into consideration the specific qualities that the brand possesses and that make it consistent, competitive, honest and responsible (57). 
Buying decisions depend on the brand image and the quality of the product, which builds trust; good product quality creates positive behavior and makes the consumer willing to pay money to buy the product (51).

The e-trust or e-trust is defined as an attitude of safe expectation in a situation of risk online that one's vulnerabilities will not be exploited. Trust is emerging as a potentially central aspect that leads to the acceptance of information technologies and is especially necessary for online marketers (41)(35).

Thus, e-trust can be described as the degree of conviction that customers have in online exchanges or in online exchange channels (55). In this sense, in online purchases, trust influences consumers' willingness to buy online, e-trust influences online sales and the value perceived by the customer (58).

H5. Consumer confidence towards the online marketing channel directly and positively influences the online purchase intention of the MiPyMe consumer.

\section{Satisfaction}

Satisfaction is an indicator to increase consumer loyalty, however, to guarantee loyalty, other factors such as trust are required (59). In today's business environment, characterized by high existing competitiveness, repeat purchases are a necessary phenomenon in order to guarantee the survival of organizations, which will lead to customer retention (36).

The quality of a product are the characteristics that contribute to the ability to satisfy a certain demand, quality is what the consumer expects (51). Consequently, satisfying customer needs is the key to exchanges between companies and the market, and since the origins of marketing, satisfaction has been considered as the determining factor of success in markets (60).

According to the customer theory of value, satisfaction is the result of the perception of the value received by the customer over the expected value, so that loyalty is the result of the belief of customers that the amount of value received It is superior to what you can get from other sellers. In this perspective, loyalty is defined as attitude and behavior, where the intention to buy back is linked to customer satisfaction (37).

H6. Satisfaction positively influences the online purchase intention of the consumer of the MiPyMe online clothing store.

\section{Perceived value}

Perceived value refers to the evaluation that customers make of products or services after weighing the perceived benefits and sacrifices (28). A general evaluation of the perception of differences between consumers who pay and obtain in the purchase process; In relation to perceived benefits and costs, buyers will choose the option that offers the highest perceived value (52) (8).

Perceived value can better reflect consumers' purchasing intent, in order to achieve the purpose of predicting consumer behavior (28). The perceived value as the result of a triggering background of the perceived price (quality and perceived sacrifice) (31). The perceived value according to (9) covers six dimensions: functional value, emotional value, social value, image value and cognitive value, including in the dimensions of value perceived by the customer of personalized clothing, experience, service and quality.

On the other hand, the utilitarian value provided by the convenience of technology and the improvement of the efficiency of purchases can improve consumer satisfaction, increase the desire to consume and promote reconsumption (52). The digital strategy increases product sales; therefore, the retail trade needs business model innovation to better understand the value of technological innovation (10).

Zeithaml (1988) cited by (61) indicates that consumers come into contact with the perceived value, once they have that first encounter with the product or service during the purchase (p.3), they evaluate the cost vs. profit, and compare the value offer against 
that of the competition (62). According to Kwon et al. (2003) cited by (63) and (62), the perceived value has a direct impact on: a) the purchase intention, $b$ ) the behavior observed in the purchase process, in the act of purchase and in repurchase, and c) in customer satisfaction, as a result of the comparison between perceived value and expectations; is directly related to: a) emotional reactions and b) shopping experience, according to Lee and Lim (2000) and Moliner et al. (2007).

Utilitarian value is the value that consumers receive from the e-commerce website visited, based on the collection of information related to the product that helps them make more informed purchasing decisions (65). In relation to e-commerce websites, the utilitarian value can be benefited through interactivity, which allows, increase the perceived quality and decrease the sensitivity to the price; however, long waiting times can have the opposite effect on consumer perceived value (66).

\section{H7. Perceived value positively influences consumer satisfaction of the MiPyMe online clothing store}

\section{Materials and Methods}

The objective of the research was to find out the purchase intention of young consumers' clothing through the online channel of the MiPyMe located in the countries of Mexico, Colombia and Peru. To do this, by means of a structural equation model, it is intended to analyze the relationships between the variables trust, satisfaction, perceived value, quality of interaction, loyalty and image in the electronic context as antecedent variables of the online purchase intention, according to the exposed in the theoretical framework of the present investigation.

Construction of the model

With the evidence found in the literature, the hypotheses were raised in the theoretical framework to contrast in the present study.

These relationships are shown in Figure 1, in order to show the theoretical graphic model on which the research is based.

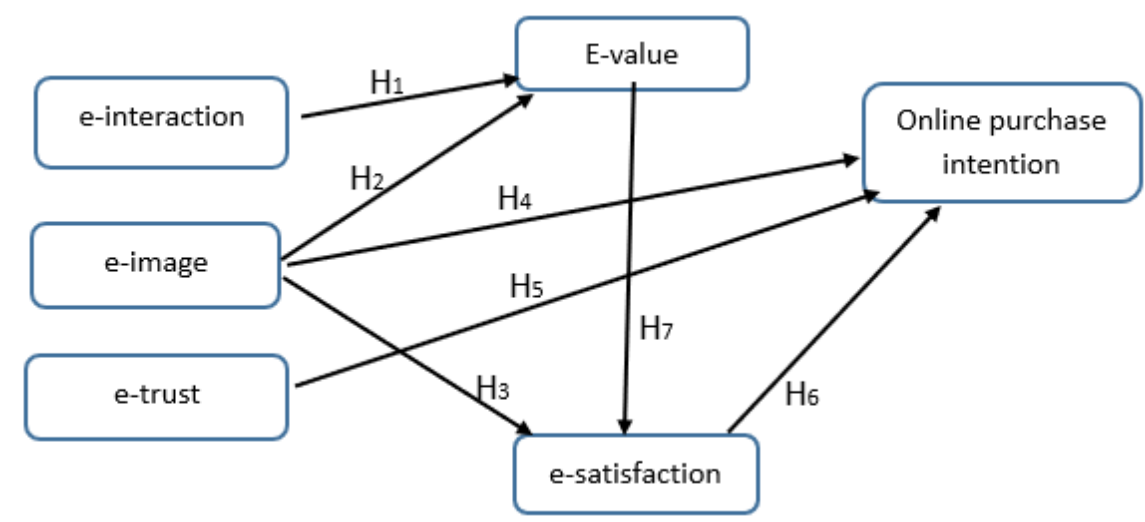

Figure 1. Theoretical model

\section{Data collection}

The measuring instrument was designed according to the theoretical bases. The questions were validated by 4 specialists from the three countries involved in the study, to ensure the clarity of the questions and for this a pilot sampling was carried out to measure the reliability of the instrument. The questionnaire was distributed virtually, the link of which was distributed to a convenience sample through emails and social networks to the different young people in each city. Informed consent was provided at the beginning of 
the questionnaire, where the study objective was clarified to the participants, that their participation was voluntary and that their data would be treated anonymously. At the end of the informed consent, the participants had to press the acceptance option to enter the questionnaire.

Table 1. Technical file of the investigation

\begin{tabular}{|l|l|}
\hline \multicolumn{1}{|c|}{ Item } & \multicolumn{1}{c|}{ Description } \\
\hline Universe & Young citizens ICT users \\
\hline Geographical scope & Perú, Colombia and Mexico. \\
\hline Answered questionnaires & 638 \\
\hline Removed questionnaires & 0 \\
\hline Sample size & 638 \\
\hline Sample design & Via internet through Google Form \\
\hline Information collection period & June 05 to July 28, 2021 \\
\hline Sampling type & For convenience \\
\hline Confidence level & $95 \%$ \\
\hline Statistical techniques & AFC-SEM \\
\hline
\end{tabular}

\section{Statistical procedures}

The data were analyzed using the structural equation model (SEM), and since the data collected did not meet normality, the unweighted least squares technique was used. This technique was used because it provides results with statistical significance.

\section{Results and Discussion}

In this study, 638 surveys were applied to young consumers in Mexico, Colombia and Peru. Sociodemographic characteristics included gender, age, country and knowledge of an online clothing store of a MiPyMe, as shown in table 2.

Table 2. Technical file of the investigation $(\mathrm{N}=638)$

\begin{tabular}{|l|l|l|l|}
\hline \multicolumn{1}{|c|}{ Characteristics } & \multicolumn{1}{|c|}{ Category } & \multicolumn{1}{c|}{ Frequency } & $\begin{array}{c}\text { Percentage } \\
\text { (\%) }\end{array}$ \\
\hline Gender & Feminine & 385 & 60.3 \\
& Male & 253 & 39.7 \\
\hline Age & $16-20$ & 239 & 37.5 \\
& $21-25$ & 232 & 36.4 \\
& $26-30$ & 63 & 9.9 \\
Country & More than 30 & 104 & 16.3 \\
& Perú & 213 & 33.4 \\
Meet an online & Colombia & 221 & 34.6 \\
clothing store of a & No & 204 & $32 \%$ \\
MiPyMe & Mexico. & 400 & 37.3 \\
\hline
\end{tabular}

A sample was identified where the female gender predominated $(60.3 \%)$, the ages between 16 to 20 years (37.5\%) and 21 to 25 years (36.4\%), and a similar number of participants in the three Latin American countries: Mexico (32\%), Colombia (34.6\%) and Peru (33.4\%); Likewise, of the total of young people surveyed, $62.7 \%$ stated that they did not know of any online clothing store of a MiPyMe. The fact that women answered the questionnaire more than men, leads us to reflect that it is perhaps women who have a greater inclination towards buying online, as well as a greater participation in commercial research, however, the literature It does not show reliable antecedents that allow us to sustain a position in relation to gender. On the other hand, the age range with the highest percentage was 16 and 25 years old, a young population that belongs to generation $\mathrm{Z}$ and 
that adapts to new technologies with great ease, that has not interacted with a virtual clothing store of a MiPyMe shows us that companies are not applying correct digital strategies or are simply unaware of the use of digital marketing tools (67).

A situation, which can be explained in relation to the abrupt digital transformation that MiPyMe suffered as a result of the Covid-19 pandemic (1), where many of them launched into electronic commerce without having the technical skills and adequate infrastructure to optimally use digital media for business purposes (68). Even though the adoption of electronic commerce has a positive and significant influence on the sales of MSMEs, with the use of ICT (2), it is necessary to strengthen plans and strategies for digital marketing, communication media, as well as to strengthen technological capacity and operation, in addition to having trained personnel in order to facilitate the process (69) (Suárez, 2020); given that technology, fashion, innovations and cultural patterns respond to globalization, and pose a challenge for the survival of MSMEs and their competitive positioning in a new increasingly demanding digital market $(70)(10)(34)(8)(37)$.

The objective of the research was to know the purchase intention of young consumers' clothing through the online channel of small and micro companies located in the countries of Mexico, Colombia and Peru. Therefore, for the statistical analysis and the verification of the hypotheses raised, only the participants who knew at least one online clothing store belonging to a MiPyMe were considered. Table 3 shows the goodness of fit and tables 7 and 8 present the validation of the final measurement model with reliability and convergent validity.

Table 3. Goodness of Fit

\begin{tabular}{|c|}
\hline Goodness-of-fit measures \\
\hline 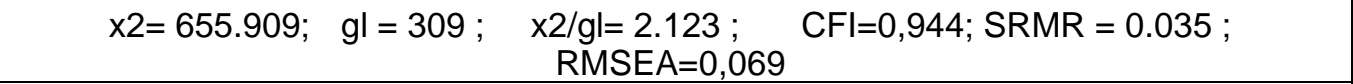 \\
\hline $\begin{array}{l}\text { Hu and Bentler (1999, "Cutoff Criteria for Fit Indexes in Covariance Structure Analysis: } \\
\text { Conventional Criteria Versus New Alternatives") recommend combinations of } \\
\text { measures. Personally, I prefer a combination of CFI }>0.95 \text { and SRMR<0.08. To further } \\
\text { solidify evidence, add the RMSEA<0.06. }\end{array}$ \\
\hline
\end{tabular}


Table 4. Validation of the final measurement model and convergent validity

\begin{tabular}{|c|c|c|c|c|c|c|}
\hline Variable & $\begin{array}{c}\text { Indica- } \\
\text { tor }\end{array}$ & $\begin{array}{c}\text { Factor } \\
\text { Loading }\end{array}$ & Robust & $\mathrm{CA}(\alpha)$ & CR & AVE \\
\hline $\begin{array}{l}\text { Interaction } \\
\text { quality } \\
\text { (CA) }\end{array}$ & $\begin{array}{l}\text { CA1 } \\
\text { CA2 * } \\
\text { CA3 } \\
\text { CA4 } \\
\text { CA5 }\end{array}$ & $\begin{array}{l}.769^{* * *} \\
.791^{* * *} \\
.763^{* * *} \\
.751^{* * *} \\
.676^{* * *}\end{array}$ & $\begin{array}{l}13.726^{* * *} \\
14.305^{* * *} \\
13.554^{* * *} \\
13.273^{* * *} \\
11.491^{* * *}\end{array}$ & 0.863 & 0.866 & 0.564 \\
\hline $\begin{array}{l}\text { Trust } \\
(\mathrm{CO})\end{array}$ & $\begin{array}{l}\mathrm{CO} 1 \\
\mathrm{CO} 2 \\
\mathrm{CO} 3 \\
\mathrm{CO} 4 \\
\mathrm{CO} 5 *\end{array}$ & $\begin{array}{l}.882^{* * *} \\
.752^{* * *} \\
.884^{* * *} \\
.890^{* * *} \\
.845^{* * *}\end{array}$ & $\begin{array}{l}17.150^{* * *} \\
13.428^{* * *} \\
17.209^{* * *} \\
17.400^{* * *} \\
16.004^{* * *}\end{array}$ & 0.929 & 0.93 & 0.726 \\
\hline $\begin{array}{l}\text { Image } \\
\text { (IM) }\end{array}$ & $\begin{array}{l}\text { IM1 } \\
\text { IM2 } \\
\end{array}$ & $\begin{array}{l}.905^{* * *} \\
.931^{* * *}\end{array}$ & $\begin{array}{l}17.707^{* * *} \\
18.552^{* * *}\end{array}$ & 0.913 & 0.914 & 0.842 \\
\hline $\begin{array}{l}\text { Satisfac- } \\
\text { tion } \\
(\mathrm{SA})\end{array}$ & $\begin{array}{l}\text { SA1 } \\
\text { SA2 } \\
\text { SA3 } \\
\text { SA4 * } \\
\text { SA5 }\end{array}$ & $\begin{array}{l}.846^{* * *} \\
.805^{* * *} \\
.856^{* * *} \\
.784^{* * *} \\
.825^{* * *}\end{array}$ & $\begin{array}{l}15.940^{* * *} \\
14.758^{* * *} \\
16.250^{* * *} \\
14.199^{* * *} \\
15.331^{* * *}\end{array}$ & 0.913 & 0.913 & 0.679 \\
\hline $\begin{array}{l}\text { Purchase } \\
\text { Intent } \\
\text { (INT) }\end{array}$ & $\begin{array}{l}\text { INT1 } \\
\text { INT2 } \\
\text { INT3 } \\
\text { INT4 } \\
\text { INT5 } \\
\end{array}$ & $\begin{array}{l}.903^{* * *} \\
.906^{* * *} \\
.919^{* * *} \\
.888^{* * *} \\
.845^{* * *} \\
\end{array}$ & $\begin{array}{l}17.904^{* * *} \\
17.985^{* * *} \\
18.470^{* * *} \\
17.401^{* * *} \\
16.040^{* * *}\end{array}$ & 0.95 & 0.951 & 0.797 \\
\hline $\begin{array}{l}\text { Perceived } \\
\text { Value } \\
(\mathrm{VA})\end{array}$ & $\begin{array}{l}\text { VA1 } \\
\text { VA2 } \\
\text { VA3 } \\
\text { VA4 } \\
\text { VA5 }\end{array}$ & $\begin{array}{l}.776^{* * *} \\
.820^{* * *} \\
.913^{* * *} \\
.903^{* * *} \\
.817^{* * *}\end{array}$ & $\begin{array}{l}14.039^{* * *} \\
15.234^{* * *} \\
18.155^{* * *} \\
17.810^{* * *} \\
15.159^{* * *}\end{array}$ & 0.926 & 0.927 & 0.718 \\
\hline
\end{tabular}

Cronbach's Alpha (CA) is $>0.8$ in all variables, Composite Reliability $(\mathrm{CR})>0.70$ and Average Extracted Variance (AVE) $>0.50$; which indicates a significant validity and reliability of the model.

Table 5. Validation of the final discriminant validity measurement model.

\begin{tabular}{|l|c|c|c|c|c|c|c|c|}
\hline & CR & AVE & CA & CO & IM & SA & INT & VA \\
\hline CA & 0.866 & 0.564 & $\mathbf{0 . 7 5 1}$ & & & & & \\
CO & 0.930 & 0.726 & $0.908^{* * *}$ & $\mathbf{0 . 8 5 2}$ & & & & \\
IM & 0.914 & 0.842 & $0.876^{* * *}$ & $0.888^{* * *}$ & $\mathbf{0 . 9 1 8}$ & & & \\
SA & 0.913 & 0.679 & $0.885^{* * *}$ & $0.833^{* * *}$ & $0.806^{* * *}$ & $\mathbf{0 . 8 2 4}$ & & \\
INT & 0.951 & 0.797 & $0.723^{* * *}$ & $0.720^{* * *}$ & $0.654^{* * *}$ & $0.782^{* * *}$ & $\mathbf{0 . 8 9 3}$ & \\
VA & 0.927 & 0.718 & $0.712^{* * *}$ & $0.733^{* * *}$ & $0.666^{* * *}$ & $0.795^{* * *}$ & $0.869^{* * *}$ & $\mathbf{0 . 8 4 7}$ \\
\hline
\end{tabular}

Table 5 presents the discriminant validity, which validates the measurement model provided that the confidence intervals do not reach unity and the squared covariances do not exceed the AVE. All these requirements are adjusted in the proposed model, only the variable "quality of interaction" fails to fulfill the discrimination with a correlation of 0.908, being very high with "Confidence"; however, in order not to lose important information, the researchers made the decision not to eliminate the correlated items. Therefore, we proceed with the testing of the hypotheses through the analysis of the SEM structural equation model. 


\section{Contrasting the hypotheses}

Once the measurement instrument was validated, we proceeded with the estimation of the structural model proposed with the help of a model of structural equations carried out in the AMOS-V24 program, the results of which are shown in table 9. In the same way as in the analysis confirmatory factorial, the goodness of fit, reliability and validity were evaluated to accept the results obtained in the equations and finally, to contrast the hypotheses.

Table 6. Contrasting the hypotheses of the model

\begin{tabular}{|l|l|l|l|l|l|l|}
\hline H & \multicolumn{3}{|c|}{ Influences of variables } & Estimate & p-value & $\begin{array}{c}\text { Hypothe- } \\
\text { sis }\end{array}$ \\
\hline H1 & $\begin{array}{l}\text { Interaction } \\
\text { quality }\end{array}$ & $--->$ & $\begin{array}{l}\text { Perceived } \\
\text { value }\end{array}$ & 0.571 & $* * *$ & Accepted \\
\hline H2 & Image & $--->$ & $\begin{array}{l}\text { Perceived } \\
\text { value }\end{array}$ & 0.094 & 0.491 & Rejected \\
\hline H3 & Image & $--->$ & Satisfaction & 0.456 & $* * *$ & Accepted \\
\hline H4 & Image & $--->$ & $\begin{array}{l}\text { Purchase } \\
\text { intention }\end{array}$ & 0.527 & 0.002 & Accepted \\
\hline H5 & Confidence & $--->$ & $\begin{array}{l}\text { Purchase } \\
\text { intention }\end{array}$ & 0.335 & 0.014 & Accepted \\
\hline H6 & Satisfaction & $--->$ & $\begin{array}{l}\text { Purchase } \\
\text { intention }\end{array}$ & 0.980 & $* * *$ & Accepted \\
\hline H7 & $\begin{array}{l}\text { Perceived } \\
\text { value }\end{array}$ & $--->$ & Satisfaction & 0.473 & $* * *$ & Accepted \\
\hline
\end{tabular}

Significant $>0.050 ;{ }^{* *} \mathrm{p}<0.001 ;{ }^{* *} \mathrm{p}<0.010 ;{ }^{*} \mathrm{p}<0.050$

From the results applying the structural equations model in the AMOS-V24 statistical package, the quality of fit for the structural model can be qualified as acceptable $(x 2=$ 485.945; $\mathrm{gl}=220 ; \mathrm{x} 2$ / $\mathrm{gl}=2.209 ; \mathrm{CFI}=0.947 ; \mathrm{SRMR}=0.045 ; \mathrm{RMSEA}=0.071$ ). The $\mathrm{p}$ value indicates the significance of the hypotheses raised, so that, with a significance of $p$ value $<0.001$, the hypotheses H1, H3, H6 and H7 are contrasted; With a significance of p value $<0.050$, the hypotheses H4 and H5 are contrasted. This indicates that the quality of interaction directly and positively influences perceived value, that the image directly and positively influences the satisfaction and purchase intention of the consumer of the MiPyMe of Colombia, Mexico and Peru, however, hypothesis H2 has not been tested positively. This explains that, in this study population, the image does not positively influence the perceived value. On the other hand, when verifying that the purchase intention is influenced by customer satisfaction and the latter in turn by the perceived value, it can be stated that there is an indirect but positive relationship between perceived value and the intention to purchase online, assertion which resembles previously reviewed literature.

Interaction in social networks increases the level of communication between customers and suppliers, an interaction that impacts the perceived value of the consumer, because this relationship includes the exchange of information, suggestions, requests and opinions of the good or service offered (38) (41) (43). For this reason, in order to achieve a positive relationship, it is important to strengthen the quality of the service, taking into account that the client will always compare the expectation they have versus what they actually received (40) and depending on the result they will to make the decision to continue consuming the product or, on the contrary, to look for a new one that effectively satisfies their expectations (37), even more so considering that the client incurs opportunity costs when acquiring the good or service (15), in addition to continuously receiving offers from the competition (11)(12).

The quality of interaction has the ability to increase the offer of additional content taking into account the resources that the MSME has to promote online shopping (32) (34), 
in such a way that, it will increase the perceived value of the client due to the increase in the commercial and emotional attractiveness of the product, specifically in relation to the efficiency in the purchase, which will surely allow the increase in satisfaction of the consumer, which in the short term will be reflected in the increase in their own consumption or in the social circle in which they operate due to the references delivered from the company where they purchase the products $(15,28,37)$. It should be noted that the value offer perceived by customers depends in most cases on sociodemographic and cultural conditions, the environment and individual perceptions, among others, which means that each tactic or strategy used is defined especially for the segment to which you want to get there (12).

In this framework, virtual assistants are a fundamental tool for making a purchase decision, because they increase customer service by providing an active and, in most cases, pleasant experience (39). It depends on this type of instrument that the client, in the first contact with the company, perceives emotional, social, functional, image, cognitive benefits, among others when acquiring the product because otherwise it will start to review value offers in the competition. In that order of ideas, the client can obtain a perceived utility through the fulfillment of the functional objectives in such a way that he makes the purchase decision giving greater value to the perceived quality and not to the sale price of the product, it can also decrease waiting times that will be reflected due to the quality of interaction.

Regarding the image of an online store, it does not positively influence the perceived value of the consumer, but it does influence the satisfaction and online purchase intention of the consumer of the MiPyMe online clothing store. The results show that the image has a moderate influence in some cases and not in others with respect to the perceived value variable, only $37.3 \%$ know of any textile MiPyMe with an online store, this shows that, for Micro, small and medium companies In Colombia, Mexico and Peru, digital marketing strategies must be implemented to have a greater presence among online clothing consumers. In this regard, (71) found that the image of a store influences the perceived value, provided that the quality perceived by the customer and the trust in the store maintain high levels; however, this is difficult to achieve when you have volatile online consumers who spend a lot of time comparing features and prices in different virtual stores, looking for the perfect item to suit their needs (11-14).

The value perceived by the consumer focuses on the symbolic and functional characteristics of a product, therefore, digital marketing and advertising strategies play an important role in customer satisfaction (52) (54) indicate that the image of a retailer that has an online presence promotes growth in the levels of positive perception of value, either rationally or emotionally (44), by the customer; and as (55) points out, the image makes it possible to create higher stages in relation to customer satisfaction. The image of the online store helps, among other aspects, to the construction of perception, that is, to organize the concepts that the customer has in his mind in relation to the value offer materialized in the product, which translates into an anticipated preconception of customer satisfaction. Satisfaction of previous expectations that customers have will significantly influence their intention to buy online (51), even when the product in the online store has a higher price than the competition (53)

On the other hand, it is confirmed that trust positively influences online purchase intention, so it can be stated that consumers trust a brand that provides them with security, quality and the ability to satisfy their expectations (39) (57). E-trust generates brand loyalty, drives online sales, and influences customer perceived value (41) (55) (58), therefore, the customer can interact comfortably and safely on the virtual platform during the purchase, with the confidence of obtaining the product they expect. However, there are currently many cybercrimes that governments are still unable to combat (53).

Satisfaction strongly influences the online purchase intention of the MiPyMe online clothing store consumer, as stated (59) (36) (37), satisfaction is a determining factor to increase the levels of customer loyalty and retention, passing through the stages of purchase intention, purchase and repurchase. Customer satisfaction is a fundamental element to 
guarantee customer loyalty, which is translated into the assurance of the repeated purchase act, based on the value received in each one of them, becoming a cyclical effect of multiple confirmations between both. elements (customer satisfaction and act of purchase).

It is important to note that the evaluation carried out by consumers tends to establish the relationship between the expected benefits of the product and the opportunity cost that must be incurred, in such a way that if the benefits are higher than the costs in which incurred, it is identified that the customer is satisfied (28)(52)(8). For this reason, it follows that the sustainability and growth of MiPyMe is contingent on the satisfaction that customers have with the good or service they are consuming. In such a way that all those strategies that companies use in relation to the use of Digital Marketing will give greater efficiency to purchases and this will influence customer satisfaction, which will be reflected first in customer retention and second in a greater number of own purchases or those of referenced persons.

It should be noted that the efficient use of technology increases the level of consumer satisfaction because greater value is perceived in the purchase of the product, taking into account that different types of resources are maximized, such as time and money, among others. This level of customer satisfaction will translate into a perception of value towards the company that provides the service or manufactures the good (61), which on many occasions allows establishing the customer's purchasing behavior, in such a way that the number of purchases made will be increased, in addition to inviting you to generate a commitment of loyalty with the company that provides it, because the perception is created that no competitor is going to give a greater amount of added value to the that the current company is offering you.

On the other hand, it is important to identify that the use of digital tools increases the number of sales made especially in the retail sector by increasing the level of satisfaction with the value offer presented by the company. However, it should be clarified that in order for MSMEs to be able to take advantage of these tools, they must update the technological models in virtual stores and in the use of digital marketing strategies. At the same time, it is important to indicate that there are other factors that are directly related to the level of satisfaction that a customer has, such as: shopping experience and emotions, for this reason it is important to take into account attributes of the offer based on price and quality, in addition to presenting benefits of different types and for different types of clients (9)(52)(10).

\section{Conclusions}

This study shows the relationship that the quality of interaction has with the perceived value, trust and consumer satisfaction, in such a way that the use of the MiPyMe of Peru, Colombia and Mexico can increase or decrease the purchase intention of clothes in online stores. Thus, the quality of interaction plays an important role in increasing the offer of additional content, which allows the client to increase the levels of perceived value, trust and satisfaction by identifying greater commercial and emotional value in the first instance, in such a way that the sale price of the product will surely be observed in the background.

The image of a product or company is subject to different factors, among others: the economic development of the country, international stereotypes and customer loyalty. The first factor shows that the MSMEs of the countries under study have little investment in technology due to the low economic growth in recent years. This is reflected in the marketing strategies used by micro, small and medium-sized companies, especially in the implementation of online stores, taking into account that, the greater the number of resources, the greater specificity in the strategies and tools implemented. It can be identified that the majority of consumers orient their purchases taking into account the stereotypes that in the case of the countries analyzed tend to be foreign due to the image that 
multinational companies have in developing countries. The third factor for the MSMEs under analysis is quite difficult to sustain it for a long time due to the different value offers of national and international competition, especially those that are directed directly to the lower price of the product, a factor with which MSMEs in most cases cannot compete.

On the other hand, it can be affirmed that the first contact of the MiPyMe with the consumer is essential for the client to perceive the different benefits that the company offers, even more so considering that the consumer incurs an opportunity cost when acquiring the product and therefore by not feeling a high level of satisfaction, you will surely review the different offers that the competition presents you and therefore the commitment to brand loyalty will disappear. However, it is important to note that the consumer's purchase intention is subject to different variables, including the country's economic growth and international stereotypes, which means that MSMEs have to review the different variables in order to deliver a great offer. of value to its consumers.

The study carried out benefits MiPyme from different economic sectors and countries worldwide that are implementing online stores, especially those that are located in the countries under study and that carry out their economic activity through the textile trade. This is due to the fact that the article presents the existing relationship between some variables that, when taking them into account, will allow to improve the purchase intention of current customers who had been carrying out their operations through the face-to-face mode. In addition, they will be able to increase the number of clients by attracting those potential clients who are impacted by the products and benefits that organizations present to them through the online methodology.

The project also benefits MiPyme in the sector and in the countries under investigation that, before or because of the pandemic, already have online stores but are not yet recognized due to commercial circumstances. This is due to the fact that the research suggests taking into account some variables that increase the purchase intention of customers, which can be taken into account for the implementation of new digital marketing tactics or for the improvement of existing ones in such a way that it allows increase the level of recognition of micro, small and medium-sized companies, which will result in an increase in income and therefore a higher percentage of profitability and market positioning.

It should also be mentioned that the study benefits entrepreneurs in the textile sector in Colombia, Peru and Mexico who are formulating the business plan to start up the company in the short term, supporting commercial operations through online stores. In this particular case, the article provides some variables that are considered important to take into account when observing the purchase intention of the products offered. This will allow entrepreneurs to generate strategies and tactics focused on achieving long-term customers who feel satisfied with the goods or services offered and therefore can refer the micro, small or medium-sized company from which they buy the products to other customers.

The research carried out gives guidelines to continue contributing to the development of MSMEs in the different economic sectors, mainly in Colombia, Mexico and Peru on Digital Marketing issues, even more so with the strong impact generated by the appearance of the Covid -19 pandemic at the level world. Being essential to know the reasons why digital Marketing practices are not enough for MSMEs to have great recognition in the market. In addition, it would be convenient to identify the strategies and tactics that micro, small and medium-sized companies have used to publicize their products through digital marketing. This with the aim that those companies that have not implemented digital marketing activities or that have not worked as expected carry out a benchmarking process and implement the good practices of those organizations that have had good results.

It should be noted that research can also be carried out regarding the human talent in charge of digital marketing activities in the MiPyMe of the different sectors in various countries, especially in the objects of study of this research in such a way that it is possible to inquire about the knowledge, skills and perceptions that employees have regarding digital marketing. Likewise, it is possible to investigate the motivational, conflict 
resolution, leadership, teamwork practices among others observed by the MiPyMe in front of the collaborators in charge of the management of virtual stores and / or digital marketing.

Author Contributions: Conceptualization, E.E.G.S.; methodology, E.E.G.S.; software, E.E.G.S.; validation, E.E.G.S., P.A.M.H, R.E.Z.G, and J.A.P.R.; formal analysis, E.E.G.S.; investigation, E.E.G.S., P.A.M.H, R.E.Z.G, J.C.O.M. and J.A.P.R.; resources, E.E.G.S., P.A.M.H, R.E.Z.G, J.C.O.M. and J.A.P.R.; data curation, E.E.G.S.; writing-original draft preparation, E.E.G.S., P.A.M.H, R.E.Z.G, J.C.O.M. and J.A.P.R.; writing - review and editing, E.E.G.S; visualization, P.A.M.H.; supervision, J.C.O.M.; project administration, P.A.M.H.; All authors have read and agreed to the published version of the manuscript.

Funding: This research received no external funding.

Institutional Review Board Statement: Ethical review and approval were waived for this study, due to the data are completely anonymous and informed consent was obtained at the time of original data collection

Acknowledgments: This paper was possible thanks to the financial and logistical support of the Universidad Privada del Norte, Perú, Universidad San Buenaventura, Bogotá, Colombia, Universidad de Ciencias y Artes de Chiapas con sede Villa Corzo, México, Universidad de Ciencias y Artes de Chiapas con sede Villa Corzo, México and Universidad Autónoma del Perú, Perú.

Conflicts of Interest: The authors declare no conflict of interest.

\section{References}

1. Saaludin N, Saad A, Mason C. Intelligent Size Matching Recommender System: Fuzzy Logic Approach in Children Clothing Selection. IOP Conf Ser Mater Sci Eng. 2020;917(1).

2. Alderete MV. Electronic commerce contribution to the SME performance in manufacturing firms: A structural equation model. Contaduria y Adm. 2019;64(4):1-24.

3. Chen Y, Yang Z. The behavioral analysis of choice difficulty states during clothing online shopping. Int J Cloth Sci Technol. 2020;(2014).

4. Forbes. Minoristas: tendencias de consumo digital que definen la era pandémica [Internet]. 2021 [cited 2021 Jun 27]. Available from: https://www.forbes.com.mx/ad-minoristas-tendencias-consumo-digital/

5. Forbes. Comercio electrónico en México seguirá creciendo a doble dígito [Internet]. 2021 [cited 2021 Jun 27]. Available from: https://www.forbes.com.mx/comercio-electronico-en-mexico-seguira-creciendo-a-doble-digito/

6. CCCE. Informe del comercio electrónico en el primer trimestre de 2021 - Camara Colombiana de Comercio Electrónico [Internet]. 2021 [cited 2021 Jun 27]. Available from: https://www.ccce.org.co/gestion_gremial/informe-del-comercio-electronico-en-el-primer-trimestre-de-2021/

7. Palomino Pita AF, Carolina MV, Oblitas Cruz JF. E-commerce and its importance in times of covid-19 in Northern Peru. Rev Venez Gerenc. 2020;25(3):253-66.

8. Acquila-Natale E, Iglesias-Pradas S. A matter of value? Predicting channel preference and multichannel behaviors in retail. Technol Forecast Soc Change. 2021;162(October 2020):120401.

9. Yu X, Wang J. Customer perceived value evaluation method of men's shirts customization under internet environment. Fangzhi Xuebao/Journal Text Res. 2020 Mar 15;41(3):136-42.

10. Shao P, Liang J. Research on omnichannel integration model of clothing brands in new retail era. Fangzhi Xuebao/Journal Text Res. 2020 Jan 15;41(1):150-7.

11. Mo X, Sun E, Yang X. Consumer visual attention and behaviour of online clothing. Int J Cloth Sci Technol. 2020;33(3):30520.

12. Rosmayani, Mardhatillah A. Model of intention to behave in online product purchase for Muslim fashion in Pekanbaru, Indonesia. J Islam Mark. 2020;11(6):1419-41.

13. Turkut U, Tuncer A, Savran H, Yilmaz S. An Online Recommendation System Using Deep Learning for Textile Products. In: 2020 - 2nd International Congress on Human-Computer Interaction, Optimization and Robotic Applications, Proceedings. 2020. p. 6-9.

14. Danaher PJ, Danaher TS, Smith MS, Loaiza-Maya R. Advertising Effectiveness for Multiple Retailer-Brands in a Multimedia and Multichannel Environment. J Mark Res. 2020;57(3):445-67.

15. Bulovic V, Covic Z. The Impact of Digital Transformation on Sustainability in Fashion Retail. SISY 2020 - IEEE 18th Int Symp Intell Syst Informatics, Proc. 2020;149-54.

16. Jiang $\mathrm{R}, \mathrm{Wu} \mathrm{Y}$, Jin $\mathrm{P}$, Shen L. Influence of the covid-19 epidemic on clothing retail industry and development trend forecast. Wool Text J. 2020 Dec 1;48(12):98-102. 
17. Presidencia Nacional de ACOPI y FAEDPYME internacional y Colombia. Relexiones y propuestas para la reactivación y fortalecimiento de las mipymes en Colombia en el marco del COVID-19. Colombia; 2020.

18. Presidencia Nacional de ACOPI y FAEDPYME internacional y Colombia. Relexiones y propuestas para la reactivación y fortalecimiento de las mipymes en Colombia en el marco del COVID-19. 2020.

19. Departamento Nacional de Planeación. Bases Plan Nacional de Desarrollo 2018-2022. Pacto por Colombia, pacto por la equidas. Grupo de Comunicaciones, editor. Bogotá; 2019. 1457 p.

20. Consejo Nacional de Política Económica y Social. Documento CONPES 4023. Colombia; 2021 p. 183.

21. Consejo Nacional de Política Económica y Social. Documento CONPES 4011. Colombia; 2020 p. 94.

22. Liévano JP, Thomas JC, Molano R, Valero EH, Mendoza ML. Desempeño financiero del sector textil año 2018. Superintendencia de Sociedades. Bogotá; 2019.

23. Superintendencia de Sociedades. Abecé sobre acciones implementadas por el Gobierno Nacional frente al Coronavirus Covid-19 pensando en el Sector Empresarial. Superintendencia de Sociedades. 2020;15.

24. Superintendencia de Sociedades. Abecé sobre acciones implementadas por el Gobierno Nacional frente al Coronavirus Covid-19 pensando en el Sector Empresarial. 2020;15.

25. INEGI. Resultados de la segunda edición del ECOVID-IE. 2020;26.

26. EDN. Estudio sobre la demografía de los negocios 2020. 2020.

27. INEI. Encuesta De Opinión Sobre El Impacto Del Covid-19 En Las Empresas. Instituto Nacional de Estadística e Informática. 2020.

28. Suo L, Lu RC, Lin G Di. Analysis of factors inuencing consumers' purchase intention based on perceived value in e-commerce clothing pre-sale model. J Fiber Bioeng Informatics. 2020;13(1):23-36.

29. Alonso Rivas J, Grande Esteban I. Comportamiento del consumidor. Decisiones y estrategias de marketing. 8th ed. 2017. $27-29 \mathrm{p}$.

30. Cooke R. ProQuest Ebook Central. Charlest Advis. 2017;19(2):39-43.

31. Peña García N. El valor percibido y la confianza como antecedentes de la intención de compra online: el caso colombiano. Cuad Adm. 2014;30(51):15-24.

32. Xia H, Pan X, Zhou Y, Zhang Z (Justin). Creating the best first impression: Designing online product photos to increase sales. Decis Support Syst. 2020;131(December 2019):113235.

33. Moslehpour M, Thanh HLT, van Kien P. Technology perception, personality traits and online purchase intention of taiwanese consumers. Stud Comput Intell. 2017;753:392-407.

34. Moslehpour M, Pham VK, Wong WK, Bilgiçli I. e-purchase intention of Taiwanese consumers: Sustainable mediation of perceived usefulness and perceived ease of use. Sustain. 2018;10(1).

35. Chen T. Personality Traits Hierarchy of Online Shoppers. Int J Mark Stud. 2011;3(4):23-39.

36. Sánchez R, Iniesta Bonillo M íongeles, Cervera Taulet A, Schlesinger Díaz MW. Modelo integrado de antecedentes y consecuencias del valor percibido por el egresado. Rev Venez Gerenc. 2012;16(56):519-43.

37. Foroudi P, Cuomo MT, Foroudi MM. Continuance interaction intention in retailing: Relations between customer values, satisfaction, loyalty, and identification. Inf Technol People. 2020;33(4):1303-26.

38. Fu JR, Lu IW, Chen JHF, Farn CK. Investigating consumers' online social shopping intention: An information processing perspective. Int J Inf Manage. 2020;54(January 2018):102189.

39. Song YJ, Lee Y. Perceived Service Quality through Cognitive Communion of Social Live Streaming Service (SLSS) of Fashion Product and Moderating Effect of Purchasing Experience. J Korean Soc Cloth Text. 2020;44(4):639-56.

40. José Ramón Sarmiento Guede. La experiencia de la calidad de servicio online como antecedente de la satisfacción online: estudio empírico en los sitios web de viajes. Rev Investig Turísticas. 2017;(13):30-53.

41. Bhat SA, Darzi MA. Online Service Quality Determinants and E-trust in Internet Shopping: A Psychometric Approach. J Decis Makers. 2020;45(4):207-22.

42. Lind M, Salomonson N. The role of virtual servants in e-interaction. Lect Notes Informatics (LNI), Proc - Ser Gesellschaft fur Inform. 2006;P-89:124-38.

43. Li L, Huang Q, Yeung KH, Jian Z. Human-computer interaction and value co-creation in electronic service. Ind Manag Data Syst. 2018;118(1):218-35.

44. Islam JU, Rahman Z. Examining the effects of brand love and brand image on customer engagement: An empirical study of fashion apparel brands. J Glob Fash Mark. 2016;7(1):45-59.

45. Islam JU, Rahman Z. Examining the effects of brand love and brand image on customer engagement: An empirical study of fashion apparel brands. J Glob Fash Mark. 2016 Jan 2;7(1):45-59.

46. Larasati MA, Agustin CA. Pomelo Fashion Brand Image Effect On Product Purchase Interest In Young Women In Indonesia. Int J Sci Technol Res. 2019;8(7):240-3.

47. Shim SI, Lee Y. Developing a scale to measure brand image attributes of fashion brands -focused on attribute symbolism-. J Korean Soc Cloth Text. 2017;41(6):977-93.

48. Martínez E, Montaner T, Píña JM. Propuesta de medición dela imagen de marca: Un analisis aplicado a las extensiones de marca. Rev Astur Econ. 2005;(33):89-112.

49. Villena-Manzanares F, Galiano-Coronil A, Ravina-Ripoll R. Entrepreneurial culture, corporate imagen and export performance: An empirical study. Espacios. 2018;39(50).

50. David M, Lopez R. Approach To the Trust Measurement. 2006;119-30. 
51. Suharto, Ligery F, Al Shikhy AI, Yuliansyah Y. Purchasing decision using mediation of trust in product quality and brand image. Opcion. 2019;35(Special Issue 21):1091-106.

52. Yin J, Qiu X. AI Technology and Online Purchase Intention: Structural Equation Model Based on Perceived Value. Sustainability. 2021 May 18;13(10):5671.

53. Atmojo RNP, Mahesa R, Wandoko W, Tjhin VU, Prabowo H, Budiastuti D, et al. Research plan development concerning eimage impact towards online purchase intention and premium pricing strategies in Indonesia community based online market. In: Proceedings - 2015 International Conference on Science in Information Technology: Big Data Spectrum for Future Information Economy, ICSITech 2015. 2016. p. 141-6.

54. Hopkins CD, Alford BL. Pioneering the Development of a Scale to Measure ETailer Image. J Internet Commer. 2005;4(4):7999.

55. Al-Bourini FA, Aljawarneh NM, Almaaitah MF, Altahat S, Alomari ZS, Sokiyna M. The role of E-Word of mouth in the relationship between online destination image, E-satisfaction, E-Trust \& E-Service quality for international tourists perception. J Inf Technol Manag. 2021;13:92-111.

56. Morgan RM, Hunt SD. The Commitment-Trust Theory of Relationship Marketing. J Mark. 1994;58(3):20.

57. Vargas Rocha FR, De Esteban Curiel J, Luiz Rodrigo MC. La relación entre la confianza y el compromiso y sus efectos en la lealtad de marca. Rev Metod Cuantitativos para la Econ y la Empres. 2020;29:131-51.

58. Khairo T, Al Daabseh I, Aljarah A. The relationship between online sale and customer value co-creation: The mediating role of e-satisfaction and e-trust. Int J Data Netw Sci. 2021;5:97-106.

59. Segoro W, Limakrisna N. Model of customer satisfaction and loyality. Utop y Prax Latinoam. 2020;25(Extra1):166-75.

60. Sánchez Pérez M, G Gallarza M, Berenguer Contrí G, Gil Saura I. Encuentro de servicio, valor percibido y satisfacción del cliente en la relación entre empresas. Cuad Estud Empres. 2005;(15):47-72.

61. Chen L, Qie K, Memon H, Yesuf HM. The empirical analysis of green innovation for fashion brands, perceived value and green purchase intention-mediating and moderating effects. Sustain. 2021 Apr 2;13(8):4238.

62. Kotler P, Keller K. 1 Dirección de Marketing 14ed - Kotler y Keller.pdf. 2012. 657 p.

63. Kim N, Chun E, Ko E. Country of origin effects on brand image, brand evaluation, and purchase intention: A closer look at Seoul, New York, and Paris fashion collection. Int Mark Rev. 2017;34(2):254-71.

64. Kotler P, Keller KL. Dirección de marketing. 2012.

65. Wang X, Wang Y, Lin X, Abdullat A. The dual concept of consumer value in social media brand community: A trust transfer perspective. Int J Inf Manage. 2021;59(February):102319.

66. Yoo WS, Lee Y, Park JK. The role of interactivity in e-tailing: Creating value and increasing satisfaction. J Retail Consum Serv. 2010 Mar;17(2):89-96.

67. Armijos Delgado NM. Marketing Digital: una herramienta para potenciar y promocionar las Mypimes en el ámbito internacional. INNOVA Res J. 2019;4(1):1-8.

68. Chatterjee S, Kumar Kar A. Why do small and medium enterprises use social media marketing and what is the impact: Empirical insights from India. Int J Inf Manage. 2020;53(March):102103.

69. Suárez S. El comercio electrónico (e-commerce) un aliado estratégico para las empresas en Colombia. Rev Ibérica Sist e Tecnol Informação. 2020;235-51.

70. Striedinger Meléndez MP. Marketing digital transforma la gestión de Pymes en Colombia. Cuad Latinoam Adm. 2018;14(27).

71. Konuk FA. The role of store image, perceived quality, trust and perceived value in predicting consumers' purchase intentions towards organic private label food. J Retail Consum Serv. 2018 Jul 1; 43:304-10. 